\title{
ANOMALOUS CLINICAL PICTURES OF VARICELLA
}

\author{
Luis F. de Salles-Gomes, M.D.(São Paulo) \\ Virologist, \\ Instituto Adolfo Lutz, São Paulo, Brazil
}

\author{
Carlos G. Machado, M.D.(Rio de Janeiro) \\ Consultant Clinician, \\ Hospital de Isolamento 'Emilio Ribas', São Paulo, Brazil
}

THE clinical picture of varicella, like that of other infectious diseases, presents wide variation. Besides the known irregularities in rash distribution, anomalies of the prodromal period and of the exanthem have been described (Schamberg and Kolmer, 1928a; Ronaldson and Kelleher, 1938). In the present paper, the relevant features of five cases are presented and the apparent association of the anomaly with a previous skin condition is pointed out in three cases.

All five cases were observed between 1954 and 1955 when no laboratory technique was available for identification of varicella virus or antibody. In three cases, fluid collected from vesicles was inoculated on the chick-embryo chorioallantois after treatment with a mixture of penicillin and streptomycin. Reinoculations of the original inocula and serial blind passages were made to eliminate the possibility of variola virus being the agent involved since this virus may sometimes fail to provoke typical lesions (MacCallum, 1954). Besides, the failure to find chorioallantoic lesions supported the clinical diagnosis since varicella virus does not provoke lesions (Irons, Bohls, Cook and Murphy, 1941; MacCallum, 1954). Biopsies of representative skin lesions were made in two cases and the histological findings were interpreted in the light of recent reviews of the pathology of viral pocks (Lever, I949; McNair Scott, Blank, Coriell and Crouse, 1950).

\section{Case No. I: Varicella Complicated by Pemphigoid Bulla (Varicella Bullosa)}

A white female infant was suffering from typical infantile eczema when she developed varicella at a suggestive interval after her older sister. In the latter, the malady was typical as were pock morphology and distribution in Case No. I except where the eczematous lesions affected the face, neck and chest. In the latter regions numerous large flaccid bullæ appeared whose roof easily tore off, uncovering the hæmorrhagic, eroded base. The relationship of the eczematous patches to the area where bullæ appeared was obvious because of the limited area covered by the eczema and the occurrence of typical varicellous pocks in the rest of the body. No virus could be isolated on the chorioallantois from the fluid content of several vesicles.

\section{Case No. 2: Varicella Complicated by Pemphigoid Bullz (Varicella Bullosa)}

An adult white male exhibited a varicellous exanthem showing striking differences among the body regions. The face, chest, abdomen and the ventral aspect of the neck and both arms exhibited an accumulation of pemphigoid bullæ containing a clear greyish fluid. Many bullæ were actually in contact and were up to two or more centimetres in size so that the chest skin, and particularly the skin of the abdomen, was hidden by a coat of bullæ. On the other hand, the exanthem was sparse on the rest of the body where the pocks had a centripetal distribution and showed marked differences in size, shape and development in a given region.

Comment. Unfortunately a biopsy of lesions from the bullæ and vesicle areas was not made. The characteristics of the non-bullous exanthem were sufficiently typical for a clinical diagnosis of chickenpox. The negative results of inoculations on the chorioallantois supported this diagnosis. Questioning of the patient did not yield useful information about previous conditions related to the skin areas covered by the bullous eruption. The regional differences of rash characteristics strongly suggested that the area covered by bullæ presented some disturbance provoking formation of these large collections of liquid. No bullæ but vesicles were seen in other areas, thus composing a highly significant control. Furthermore, the lower limit of the area covered by bullæ was beneath the umbilicus and was neatly linear, following the trousers waistband. The same linear limit was prominent in both arms and neck since bullæ neatly stopped on the line separating the ventral from the dorsal aspects. These characteristics suggest that the ventral aspect of the patient's body had previously been exposed to sunlight or similar radiation with the body covered only by the trousers. The seemingly irradiated area developed bullæ instead of vesicles when the chickenpox rash appeared. This interpretation is in line with the findings in Case No. I.

Case No. 3: Varicella Complicated by Increased Lesion Density in Skin Area Previously Submitted to Drug Treatment

A white boy presented a bruise on a small area of the 
left leg to which compresses wet with a solution of lead acetate were applied. Five days later, when the patient took off the last compress, he observed a few pocks on the treated area and presented systemic manifestations. The next day a scanty pock eruption appeared with a body-distribution and lesions characteristic of chicken-pox. This clinical diagnosis was confirmed by histological examination of a vesicle and was supported by the negative result of chick embryo inoculations.

Comment. While the varicellous exanthem was composed of scanty lesions, the area covered by the wet compresses showed a striking number of pocks contrasting with the symmetrical area of the opposite leg. The accumulation of lesions was not greater on the bruise area which was definitely smaller than that covered by the wet compress, but it was more or less uniformly distributed all over the latter area. This fact, together with the linear limits of the pock accumulation, indicates that it was the chemical irritation and not the bruise which determined a condition favouring the appearance of a relatively large number of pocks. These were typical vesicles and thus they did show the exaggerated size observed in Case No. 2 for instance.

\section{Case No. 4: Confluent Pustular Varicella Mimicking Smallpox}

Shortly before his death a white male newborn was seen exhibiting an extremely profuse pock exanthem distributed all over the body, including the scalp. Pocks looked like pustules, many of them were umbilicated and there was confluence in many areas. The resemblance to a confluent smallpox exanthem was so close as to confuse numerous clinicians with long experience in variola and varicella. Only histological examination of several skin pocks was made and it depicted a most typical picture of varicellous pocks with abundant formation of intranuclear inclusion bodies and rather numerous virus giant cells. No intracytoplasmic inclusion body (Guarnieri body) was seen nor was reticular degeneration prominent. These findings were constant in the specimens examined and they practically eliminate smallpox as a diagnostic possibility, although material for virus isolation was, unfortunately, not collected. However, the same histologic picture may be seen in herpes simplex skin lesions (Lever, 1949) and thus the case might have had a generalized herpetic eruption rather than varicella.

\section{Case No. 5: Coincidence of Tick-bite Eruption and Varicella}

A two-year-old white girl received numerous tick bites after playing in a cattle-grazing area. An eruption composed of highly pruriginous acuminated papules was noticed and numerous young ticks were taken off from the slightly conical tip of the papules. These did not show a definite pattern of distribution. The child then developed a very sparse vesicular rash which showed no specific characteristics. After a suggestive time interval two girl playmates developed typical chickenpox rashes following a few days of systemic manifestations. None of these girls had previously suffered from chickenpox.

Comment. The tick-bite eruption was adequately identified because ticks were removed from the pruriginous papules which did not become vesicles. This eruption became complicated by a vesicular rash of rapid course and apparently it was chickenpox. In this regard, the following suggestive evidence was obtained: (a) occurrence of typical chickenpox in two playmates; $(b)$ none of the adult contacts presented a similar eruption; $(c)$ this small outbreak occurred in a fairly isolated farm after Case No. 5 had come from nearby town.

\section{General Comments}

Varicella bullosa has been regarded just as $\stackrel{\overrightarrow{\bar{\Phi}}}{\vec{A}}$ complication (Schamberg and Kolmer 1928a) or as clinical form (Ronaldson and Kelleher, 1938) of chickenpox. The rarity of this type suggests $b \overline{\bar{y}}$ itself that either an abnormal factor of the host or $\$$ chance coincidence of another disease may bo responsible for the unusual bullous eruption. Cases Nos. I and 2 clearly showed that there was a association between the occurrence of bullæ and $\vec{a}$ pre-existing abnormality of the skin since bulle occurred in limited areas of the body whici strikingly coincided with eczematous patches. (Case No. I) or with a seemingly irradiated area the linearity of whose contours was highly suge gestive (Case No. 2). These findings are supfo ported by a similar association in Case No. 3 sinceo in a geometrically shaped area previously submit ted to chemical irritation there was a striking in? crease in pock density while the morphology was uniform and typical throughout the skin. In $\Phi$ cidentally, a striking profusion, even confluence? of smallpox pustules has been observed in rect angular areas where a mustard plaster or iodine. had been applied before appearance of a variol@i eruption while no increased density was observed when the application was made in the early days of the eruption (Schamberg and Kolmer 1928b) Furthermore, the association of vaccinial eruptiong with eczematous patches has repeatedly been observed (Hershey and Smith, 1945; Fries an Bourne, I949).

Regarding Case No. 4 it should be re-emphrड़ sized that the histologic findings do not allow separation of varicella from herpes simplex. Furthermore, herpes simplex virus was isolate and identified from another case also closel mimicking smallpox which was studied by the authors (Angulo and de Salles-Gomes, 1956 while Kipping and Downie (1948) reported Q generalized herpetic eruption whose differentiaton from smallpox was also impossible on clinica grounds.

In Case No. 5 there was not a true anomaly of. the varicellous exanthem but the coincidence of tick-bite eruption made the whole clinical pictures extremely confusing.

\section{Summary}

The relevant features of five cases of chickenpo with anomalous clinical pictures are presented and the apparent association of the anomaly with $\mathbb{P}^{2}$ previous skin condition is pointed out in three्ष cases. 
Case No. I showed bullæ in eczematous patches and Case No. 2 exhibited bullæ in an area with straight-line contours. In these two cases, the rest of the body showed a typical varicellous rash.

Case No. 3 showed a typical varicella exanthem all over the body but in an area of straight contours he exhibited an increased pock density. This area had been treated with compresses of lead acetate solution.

Case No. 4 exhibited an extremely profuse exanthem composed of confluent or umbilicated pustules. Pock histopathology was typical of varicella or herpes simplex. Case No. 5 presented a confusing coincidence of chickenpox and a tickbite eruption.

\section{REFERENCES}

ANGulo, J. J., and DE SAlles-Gomes, L. F. (1956): unpublished observations.

FrIes, J. H., and Borne, S. (1949): Vaccinial Infection in Children with Atopic Dermatitis, f. Allergy, $20,22$.

HerSHEY, F. B., and SMITH, W. E. (1945): Generalized Vaccinia in an Eczematous Child; Demonstration of Virus and Comment on Kaposi's Varicelliform Eruption, Amer. F. Dis. Child., 69, 33.

Irons, J. V., Bohns, S. W., Cook, E. B. M., and MurPhy, J. N. (194I): The Chick Membrane as a Differential Culture Medium with Suspected Cases of Smallpox and Varicella, Amer. F. Hyg., 33 (sect. B), 50.

KIPPING, R. H., and DownIE, A. W. (1948): Generalized Infection with the Virus of Herpes Simplex, Brit. med. F., i, 247 .

LEVER, W. F. (1949): Histopathology of the Skin, p. 200. Philadelphia: Lippincott.

MacCAllum, F. O. (1954) in: The Dynamics of Virus and Rickettsial Infections (International Symposium), p. 324. New York: Blakiston.

McNair ScotT, T. F., Blank, H., Coriell, L. L., and Crouse, H. (1950) in: The Pathogenesis and Pathology of Viral Diseases (edited by J. C. Kidd), p. 74. New York: Columbia University Press.

Ronaldson, G. W., and Kelleher, W. H. (1938): The Anomalous Forms of Varicella, Brit. Y. Child. Dis., 35-36, 22. Schamberg, J. F., and Kolmer, J. A. (1928a): Acute Infectious Diseases, p. 300. Philadelphia: Lea and Febiger.

$\longrightarrow$ - (1928b): Ibid., p. 179. 